\begin{tabular}{|l|c|c|c|l|l|}
\hline \multirow{2}{*}{$\mathcal{U}$} & F M E & \multicolumn{1}{|c|}{12135} & \multirow{2}{*}{ WILEY } & Dispatch: 9.7.15 & CE: Sangeetha \\
\cline { 2 - 3 } \cline { 5 - 5 } & Journal Code & Manuscript No. & & No. of pages: 10 & PE: Bhuvaneswari C \\
\hline
\end{tabular}

Fisheries Management and Ecology, 2015

\title{
Rapid assessment of the physiological impacts caused by catch-and-release angling on blue-finned mahseer (Tor sp.) of the Cauvery River, India
}

\author{
S. D. BOWER
}

1 Fish Ecology and Conservation Physiology Laboratory, Department of Biology, Carleton University, Ottawa, ON, Canada

\author{
A. J. DANYLCHUK \\ Department of Environmental Conservation, University of Massachusetts Amherst, Amherst, MA, USA
}

\section{R. RAGHAVAN}

Conservation Research Group (CRG), St. Albert's College, Kochi, India

Mahseer Trust, Freshwater Biological Association, Wareham, Dorset, UK

Laboratory of Systematics, Ecology and Conservation, Zoo Outreach Organization (ZOO), Coimbatore, India

\author{
S. C. DANYLCHUK
}

Fish Mission, Amherst, MA, USA

\section{A. C. PINDER}

Mahseer Trust, Freshwater Biological Association, Wareham, Dorset, UK

Faculty of Science and Technology, Bournemouth University, Poole, UK

\section{S. J. COOKE}

Fish Ecology and Conservation Physiology Laboratory, Department of Biology, Carleton University, Ottawa, ON, Canada

\begin{abstract}
Forty-nine blue-finned mahseer (Tor sp.; mean total length $458 \pm 20 \mathrm{~mm}$ ) were angled using a range of bait/lure types, angling and air exposure times in water that averaged $27 \pm 2{ }^{\circ} \mathrm{C}$ over the course of the assessment. No cases of mortality were observed, and rates of moderate and major injury were low, with $91 \%$ of mahseer hooked in the mouth. More extreme physiological disturbances (i.e. blood lactate, glucose, $\mathrm{pH}$ ) in mahseer were associated with longer angling times. Sixteen fish (33\%) exhibited at least one form of reflex impairment. Moreover, longer air exposures and angling times resulted in significant likelihood of reflex impairment. Findings suggest that blue-finned mahseer are fairly robust to catch-and-release, but that anglers should avoid unnecessarily long fight times and minimise air exposure to decrease the likelihood of sub-lethal effects that could contribute to post-release mortality.
\end{abstract}

KEYWORDS : best practices, endangered species, fish conservation, fisheries management, mahseer, recreational fisheries.

Correspondence: Shannon D. Bower, Fish Ecology and Conservation Physiology Laboratory, Department of Biology, Carleton University, Ottawa, ON, Canada (e-mail: Shannon.Bower@carleton.ca) 


\section{Introduction}

Recreational fisheries are increasingly recognised as an important fisheries sector around the globe (FAO 2 2012). Although anglers harvest some fish, catch-andrelease $(\mathrm{C} \& \mathrm{R}$; i.e. the act of returning a fish to water after landing, presumably unharmed; Arlinghaus et al. 2007) is common; it can be voluntary due to the conservation ethic of the anglers or a result of compliance with regulations that require fish to be released. The extent to which $C \& R$ behaviours practiced by anglers can act as a conservation tool in any particular fishery is a complex one, particularly when targeting endangered species (Cooke et al. In Press). Target species exhibit a wide-range of outcomes associated with $\mathrm{C} \& \mathrm{R}$ (i.e. various species respond differently to the same angling practices), suggesting research should be conducted on individual species to assess the suitability of $\mathrm{C} \& \mathrm{R}$ as a management strategy (Cooke \& Suski 2005). For example, some species may demonstrate sensitivity to air exposure or exhibit high post-release mortality rates (see numerous examples in reviews by Muoneke \& Childress 1994; Bartholomew \& Bohnsack 2005; Arlinghaus et al. 2007). Even if data are available for species known to exhibit similar physiologies, findings may not be transferable to target species occupying different habitat types, life-history stages or targeted using different angling behaviours (Cooke \& Suski 2005).

Fishery-specific research can be challenging when resources for fisheries management or data availability are limited; an issue that may be of particular concern in developing recreational fisheries in low-to middle income countries (LMICs; Bower et al. 2014) or for endangered species (Cooke et al. In Press). Rapid $\mathrm{C} \& \mathrm{R}$ assessment protocols that combine injury and mortality observations with assessments of physiological state (see Cooke et al. 2013) and reflex impairment (see Davis 2010) have been developed as a way of generating data on such key response attributes in a swift and cost-effective manner. In a $C \& R$ rapid assessment, researchers first interact with stakeholders to identify likely areas to focus research efforts based on specific elements of a fishery (e.g. gear type, angler behaviour, environmental conditions) and then use a combination of simple endpoints to obtain a snapshot of the extent to which behaviours practiced in a given $\mathrm{C} \& \mathrm{R}$ fishery may be sustainable. By combining these approaches (i.e. injury and mortality assessment, physiological analyses, reflex indicators) into a single study to generate essential baseline data for species-specific responses to $\mathrm{C} \& \mathrm{R}$ practices, rapid assessments can also serve as a tool to triage future research priorities. For example, a rapid assessment could identify the need for a larger scale assessment across multiple seasons if there is evidence of a thermal stress component or perhaps looking at different lure, bait or hook types should there be evidence of deep hooking. Essentially, a rapid assessment is the first step towards ensuring that $\mathrm{C} \& \mathrm{R}$ fisheries are sustainable and that angling practices are optimised to maintain the welfare status of fish that will be released.

Mahseer (Tor $\mathrm{sp}_{\text {. }}$ ) is a group of potamodromous cyprinids endemic to Asia. The mahseer of India are currently declining as a result of a multitude of pressures including changes in land use, agricultural run-off, hydropower projects, invasive species, overexploitation and use of damaging fishing gears (Everard \& Kataria 2011; Raghavan et al. 2011; WWF 2013). Indian populations of the Tor mahseer consist of seven species as yet identified in scientific literature, although there is still much confusion surrounding their taxonomy. Four known species are currently listed as 'Endangered' on the IUCN RedList (IUCN 2014), including the two most popular game species Tor khudree Sykes (blue-finned or the Deccan mahseer), and Tor putitora Hamilton (Golden mahseer). In India, these species are primarily targeted by subsistence and recreational fishers (Everard \& Kataria 2011; Raghavan et al. 2011). In the 1970s, recreational fishers first noted a decline in mahseer size and numbers and took action to address the problem, forming angling conservation groups and coalitions [e.g. Wildlife Association of South India (WASI)]. These groups established angling camps based on strict C\&R principles, employed guards to protect stocks from poaching and began collecting catch data (Pinder \& Raghavan 2013).

Despite the lengthy history of recreational fishing for mahseer in India, little is known about the responses of the species to common angling practices. Indeed, there are currently no known studies that have evaluated any elements of $\mathrm{C} \& \mathrm{R}$ practices (spanning injury, mortality or stress) for any mahseer species in India or anywhere within their range. To address these knowledge gaps, working in partnership with local anglers and river managers, a rapid assessment was used to evaluate $C \& R$ practices for angled blue-finned mahseer (which will be referred to as Tor sp. to reflect current taxonomic uncertainty; also see Pinder et al. In Press) in the Cauvery River, India. Results of this study can be used to support evidence-based decision making in mahseer recreational fisheries, and the rapid assessment process can support the development of species-specific best practices for recreational fisheries in data-poor LMICs that can be communicated to anglers and other relevant stakeholders. 


\section{Methods}

\section{Study site}

Angling and sampling took place along the Cauvery (Kaveri) River (Ammangala Village, Valnur; $12.457494^{\circ} \mathrm{N}, 75.960549^{\circ} \mathrm{E}$; Fig. 1) in Kodagu District (Coorg), Karnataka State, India in March, 2014. Angling on much of this stretch of river (exceptions include temple sanctuary waters and the Nisargadhama Reserve) is managed by the Coorg Wildlife Society (CWS), an NGO that coordinates $\mathrm{C} \& \mathrm{R}$ angling in the area. The river in the study site also supports a variety of other users and purposes, including local and farming use (i.e. irrigation source), subsistence fishing, religious use (i.e. temple sanctuaries) and tourism (i.e. rafting). Illegal sand-mining operations also occur on this stretch of the Cauvery (Bower personal observation). Water temperatures during the rapid assessment averaged $27 \pm 2{ }^{\circ} \mathrm{C}$.

\section{Angling practices}

Angling and sampling was conducted over the course of 3 days along a $20-\mathrm{km}$ stretch of the Cauvery by two assessment teams, each consisting of between three to six anglers and an individual responsible for processing samples and recording data. Rather than simulating fisheries, local anglers and river managers were engaged to ensure that $\mathrm{C} \& \mathrm{R}$ practices studied reflected actual practices used for blue-finned mahseer (Cooke et al. 2013; Fig. 2). To account for differences in angler expertise (anglers varied in experience from novice anglers with little fishing experience overall to expert anglers with decades of fishing experience in the study area), each angler spent time collecting fish for both groups over the course of the rapid assessment.

All anglers used light- to mid-weight spinning gear and adopted a variety of terminal tackle (hereafter collectively referred to as lure types), all of which are commonly employed in the recreational fishery, including: spoons, spinners, plugs, soft baits and a traditional flour-based dough bait locally referred to as ragi (see Fig. 3). Ragi recipes use a variety of spices and flavours, but are universally fashioned into a balled shape around a single barbed or barbless hook. Pellet floats were also used to target mahseer, a technique less commonly employed in the area. Angling took place from shore, from a dinghy and from a coracle (a traditional round-bottomed boat; Fig. 3).

\section{Rapid assessment protocols}

Over the course of the rapid assessment, 49 blue-finned mahseer were angled and processed. Prior to angling, the lure type, number of hooks and hook type (barbed or

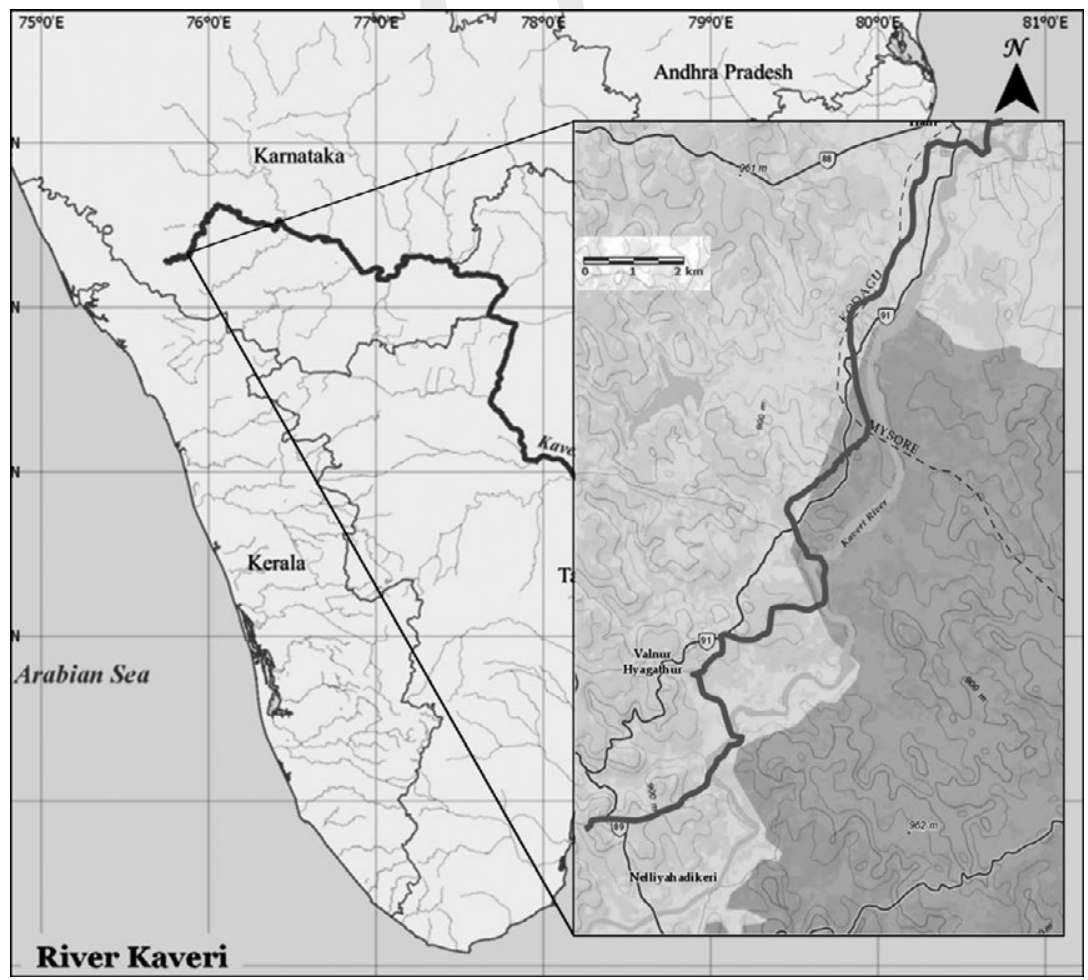

Figure 1. Location of the Cauvery River in India and the rapid assessment sampling area in Valnur, Kodagu (inset). 


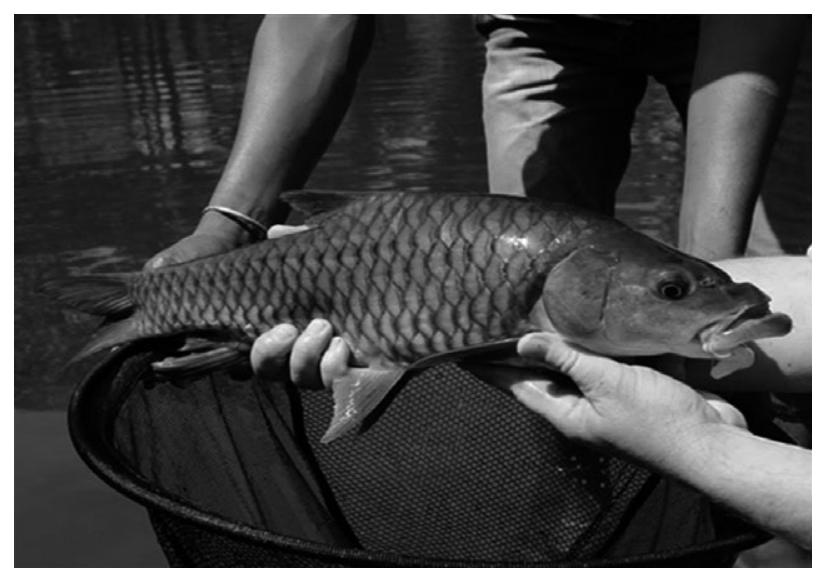

Figure 2. Blue-finned mahseer (Tor sp.) during analysis. Photo credit: Steve Lockett.

barbless) were recorded. Processing began by recording the time taken to land the fish (angling time in sec), beginning from the initial setting of the hook by the angler and terminating at landing. Once landed, the anatomical hooking location for each fish was recorded and each fish was measured (total length in $\mathrm{mm}$; TL). Fish were scored for the presence of injury using a standardised objective scoring system, where a score of 0 indicated no discernible injury; a score of 1 indicated a minor injury such as minor tearing of tissue (i.e. $<5 \mathrm{~mm}$ in length, including any visible tissue tear or abrasion resulting from hooking); a score of 2 indicated moderate injury such as the presence of bleeding, bruising or a tissue tear $>5 \mathrm{~mm}$ in length; and a score of 3 indicated major injury, such as ocular or gill damage with significant pulsatile bleeding (as per Gutowsky et al. 2011). A standardised scoring system was also applied to describe the ease of hook removal, where a score of 0 referred to a hook that was removed easily and immediately (i.e. in $<10 \mathrm{~s}$ ); a score of 1 referred to a hook that required between 10 and $20 \mathrm{~s}$ to remove; and a score of 2 was assigned when hooks required $>20 \mathrm{~s}$ to remove (a timebased variation on hook removal scores used in Cooke et al. 2001). To standardise scoring methods, only those fish scored for injury and hook removal by the assessment teams were included in analysis for these variables. Landed fish processed for non-score variables (length, lure type, hook type, angling time) by team members without a priori training in scoring standards were not included in analysis of scored variables (injury, ease of hook removal). The cumulative amount of air exposure time (s) accrued during handling was recorded by all participants.

A 'whole body' stress response in fish can take the form of immediate (e.g. inhibition of reflex behaviours) and/or delayed responses, such as decreased reproductive outputs or growth (Pankhurst \& Van Der Kraak 1997). Immediate reflex responses may be measured during a rapid assessment using reflex action mortality predictors (RAMP), indicators developed by Davis (2010). The use of indicators to measure reflex responses as proxies for physiological stress and as predictors for post-release mortality and behavioural impairment have been used in a variety of teleost fish studies (for e.g. Oncorhynchus kisutch Walbaum, Raby et al. 2012; Albula vulpes L., Brownscombe et al. 2013). With the fish submerged, RAMP indicators were measured prior to release. Four reflex indicators were used in this rapid assessment, including: 'tail grab' (fish exhibits burst swimming reflex when grabbed by the tail); 'body flex' (fish flexes torso when held along the dorsoventral axis); 'head complex' (fish exhibits steady operculum beats during handling); and, 'equilibrium' (fish rights itself within $3 \mathrm{~s}$ after being placed upside-down in water) (Davis 2010). Binary RAMP scores of 0 (reflex present) or 1 (reflex absent) were assigned to each indicator measurement, resulting in a total score ranging from $0-4$. These individual RAMP indicator scores were then combined to produce a proportional impairment score ranging from $0-1$ for


Figure 3. (a) Ragi ball affixed to a single, barbed hook; a traditional bait used in the mahseer recreational fisheries of south India. (b) Volunteer anglers fish from a coracle, a traditional round-bottomed boat used for fishing activities in south India. Photo credits: Shannon Bower. 
each fish, where 0 indicated no overall impairment and 1 indicated total impairment.

\section{Blood sampling}

In addition to measuring reflex responses, non-lethal blood samples were obtained from a subset of fish $(n=36)$ to quantify the physiological stress response of mahseer to $C \& R$ angling. These responses may be measured in a rapid assessment by obtaining a non-lethal

3 blood sample from the caudal vasculature (Barton 2002) and processed quickly in the field using point-of-care devices and techniques validated on fish and other species (as reviewed by Stoot et al. 2014). Prior to sampling, these fish were subject to the same measurements as described above. Following these measurements, fish in the blood-sampled subgroup were sampled immediately (i.e. in $<30 \mathrm{~s}$; as per Meka \& McCormick 2005).

Non-lethal blood samples were obtained by temporarily inverting fish in the water column while $<1 \mathrm{~mL}$ of blood was drawn from the caudal vasculature with a 22G needle (BD Vacutainer Multi-sample Needles and $4.0 \mathrm{~mL}$ lithium heparin collection tubes, 75 USP, Bec-

4 ton, Dickson and Company (BD), $\left.\mathrm{NJ}_{2}, \mathrm{USA}\right)$. Blood was analysed onsite immediately after withdrawal for blood lactate (mmol L ${ }^{-1}$, Lactate Pro LT-1710, Arkray Inc., Kyoto, Japan), glucose (mmol L ${ }^{-1}$, Accu-Chek Compact Plus, Roche Diagnostics, Basel, Switzerland) and $\mathrm{pH}$ (HI-99161, Hanna Instruments, Woonsocket, RI, USA). Fish that were blood sampled were released immediately after sampling was completed. All experimental manipulations performed during this study were conducted in accordance with Canadian Council of Animal Care regulations under permit number B13-02 (file \# 100105).

\section{Statistical analyses}

To determine whether angling variables such as lure type, angling time, air exposure and difficulty of hook removal influenced differences in injury score (mortality rate was not included as no cases of mortality were observed), Chi-Square (lure type, difficulty of hook removal) and Kruskal-Wallis tests (angling time, air exposure time) were employed. Tukey's HSD tests were applied as post hoc testing for all Kruskal-Wallis tests.

To evaluate stress response in blood-sampled mahseer, general linear models were applied to measure the relationship between blood values (glucose, lactate and $\mathrm{pH}$ ) and angling variables (angling time, air exposure).To normalise residuals in the model examining angling variable contributions to blood glucose values, blood glucose values were log-transformed but predictor variables were not (as recommended in Zuur et al. 2009). Contributions from uncontrolled independent variables (i.e. water temperature, ${ }^{\circ} \mathrm{C}$; TL, mm), were accounted for by including these variables in analysis. Models were chosen based on a combination of parsimony (i.e. fewest variables explaining the most variation) and minimum Akaike Information Criterion (AIC) value.

Chi-square analyses (lure type, injury score) and Kruskal-Wallis analyses (angling time, air exposure time) were performed to compare reflex impairment responses among mahseer subject to different angling times, air exposure times, lure type and injury score. RAMP scores were treated as objective measurements during analysis (RAMP scores were converted to ordinal variables; 0.0, 0.25, 0.5, 0.75, 1), a common assumption in studies using RAMP scoring (see Raby et al. 2012; Brownscombe et al. 2013; Nguyen et al. 2014 for examples). However, the low numbers of non-zero RAMP scores prevented formal statistical analysis by individual score category. Thus, non-zero RAMP scores were binned into a single category and the contributions of angling time, air exposure, lure type and injury score to non-zero RAMP scores were measured.

The dataset's compliance with assumptions of homogeneity of variance and normality of distribution were assessed using Levene and Shapiro-Wilk tests on each variable prior to analysis. Variables found to meet assumptions were treated with general linear models, while the remainder were subject to the non-parametric analyses described above. Unless otherwise noted, all data are presented as mean \pm standard error. All analyses were conducted using R (version 3.1.0, (C) 2014, The R Foundation for Statistical Computing, Vienna, Austria).

\section{Results}

\section{Injury and mortality}

Of the 44 angled blue-finned mahseer assessed for hooking location, most $(91 \%)$ were hooked in the mouth, specifically in the corner of the mouth $(n=16)$, lower jaw $(n=12)$ or upper jaw $(n=12)$. Four fish $(9 \%)$ were foulhooked, and each instance of foul-hooking was also categorised as a minor, moderate or major injury, according to the degree of resulting tissue damage. Of the 39 fish assessed for injury, 23 were classified as having minor ( $n=18$, including two instances of foul-hooking) or moderate ( $n=5$, including one instance of foul-hooking) injury, and one fish exhibited major injury in the form of a loss of perfusion to fins and damage to the 2nd gill arch after being foul-hooked in the gills.

Increases in injury score were not associated with gear-related variables such as lure type $\left(\chi^{2}=6.49\right.$, d.f. $=8, P=0.59)$, or hooking location $\left(\chi^{2}=5.60\right.$, 
d.f. $=8, P=0.69)$. Increased difficulty in hook removal $\left(\chi^{2}=5.66\right.$, d.f. $\left.=6, P=0.07\right)$, extended angling times $\left(\chi^{2}=1.13\right.$, d.f. $\left.=2, P=0.57\right)$ or extended air exposures $\left(\chi^{2}=2.34\right.$, d.f. $\left.=2, P=0.31\right)$ also did not significantly increase injury score. Finally, there were no observed instances of mortality during the course of this study, although one highly impaired and injured fish (see above) was not expected to survive over the short term.

\section{Blood chemistry}

Mean length of mahseer angled for the rapid assessment was $458 \pm 20 \mathrm{~mm}$ TL $(n=49$; range $200-700 \mathrm{~mm} \mathrm{TL})$, while fish in the blood-sampled subset $(n=36)$ averaged $443 \pm 24 \mathrm{~mm}$ TL. Mean values for blood glucose, lactate and $\mathrm{pH}$ in this sampled subset were $2.5 \pm 0.2 \mathrm{mmol} \mathrm{L}^{-1}$, $5.7 \pm 0.4 \mathrm{mmol} \mathrm{L}^{-1}$ and $7.30 \pm 0.16$ respectively. GLM models identified which angling variables (angling time, air exposure time, TL and water temperature) contributed most to variability in physiological parameters. In the model analysing factors contributing to blood lactate values, the lowest AIC value occurred when all independent variables (angling variables above) were included in the model. However, when all independent variables but angling time (the only statistically significant predictor) were removed from the model, AIC value remained low and the adjusted $R$-squared value remained stable (Adj. $R^{2}$ for full model $=0.47$, Adj. $R^{2}$ for reduced model=0.46). As such, the latter model was chosen on the basis of parsimony and revealed that elevated blood lactate values in mahseer were significantly, although weakly, correlated with longer angling times (Adj. $R^{2}=0.46, F=31.37$, d.f. $=34, P<0.001)$. The lowest AIC values in the model analysing angler variable contributions to logtransformed blood glucose occurred when all variables were retained. This model revealed that lengthened air exposure times $(t=2.73, P=0.01)$, longer angling times $(t=3.39, P=0.002)$, and shorter fish lengths $(t=-4.4$, $P<0.001)$ all correlated with increased blood glucose values (Adj. $I^{2}=0.42, F=5.13$, d.f. $=28, P=0.001$ ). Finally, angling time was also identified as being the variable contributing most to changes in blood $\mathrm{pH}$ of sampled mahseer, with the lowest AIC value and most parsimonious model occurring when all variables but angling time were removed. Extended angling times were correlated with significant decreases in mahseer blood $\mathrm{pH}$ (Adj. $I^{2}=0.55, F=7.94$, d.f. $\left.=33, P<0.001\right)$.

\section{Reflex impairment}

Mean RAMP score for the total number of fish measured for reflex impairment $(N=49)$ was 0.20 . Sixteen mahseer (33\%) tested positive for impairment for at least one of the four RAMP indicators tested. Seven of these 16 mahseer scored 0.25 , indicating impairment of a single reflex behaviour. Four mahseer scored 0.50 , indicating impairment of two reflex behaviours, and four mahseer scored 0.75 , indicating impairment of three reflex behaviours. Lastly, one mahseer scored 1.00, indicating that all four reflexes were impaired. Among the indicators measured, equilibrium, and tail grab were most commonly impaired, followed by body flex, and head complex (Fig. 3).

Air exposure, angling time, lure type and injury score were included in analyses of mahseer RAMP score. Longer air exposure times were significantly more likely to result in non-zero RAMP scores $\left(\chi^{2}=5.55\right.$, d.f. $=1$, $P=0.02)$, as were longer angling times $\left(\chi^{2}=4.02\right.$, d.f. $=1, P=0.045)$. Of the different lure types used (pellet floats, plugs, ragi, soft plastics, spinners and spoons), spinners caught the most mahseer over the study period (25 of 49 fish were angled using spinners). However, lure-specific catch-per-unit-effort was not tracked so it is unclear which lure type was most effective. Possibly due to the dominance of captures by spinners, not a single lure type was associated with a significant increase in RAMP score, suggesting that reflex impairment was not related to lure type in this study $\left(\chi^{2}=4.11\right.$, d.f. $\left.=6, P=0.53\right)$. Injured fish were also not more likely to demonstrate reflex impairment: among mahseer angled during the rapid assessment as there was no evidence of a significant relationship between injury scores $(1,2,3)$ and non-zero RAMP scores $\left(\chi^{2}=5.66\right.$, d.f. $\left.=3, P=0.12\right)$ (Fig. 4 ).

\section{Discussion}

Overall, injuries were found to be minor in nature and mortality was negligible in the mahseer rapid assessment.

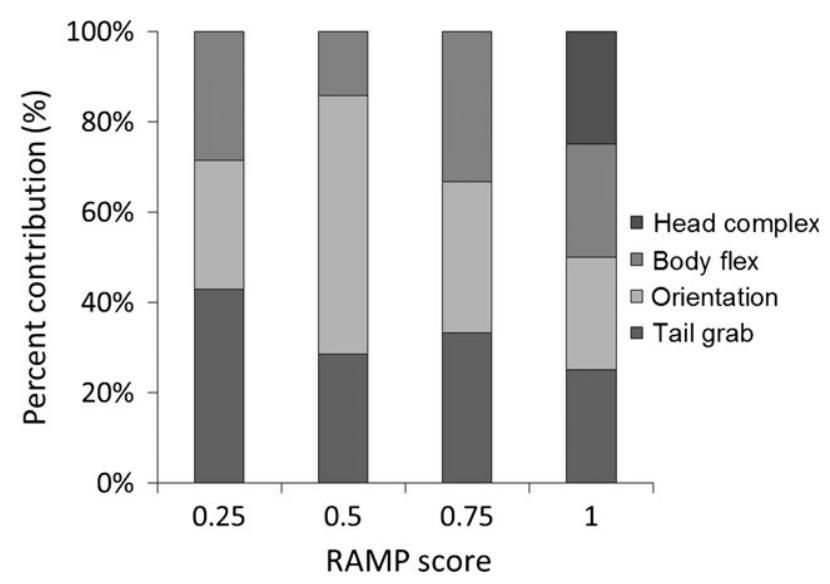

Figure 4. Proportional contributions of individual indicators to RAMP score $(0,0.25,0.5,0.75,1)$. 
A high rate of minor injury to mahseer was observed $(46 \%)$, but this was likely due to the conservative standards employed in the assessment of injury. It is worth noting that it is impossible to capture a fish by hook without causing some level of injury; an unavoidable function of hook and tissue interaction (Cooke \& Sneddon 2007). Measurements of injury were categorised using conservative standards by including any visible tissue damage, including hook puncture sites, as a minor injury and by considering a tissue tear $>5 \mathrm{~mm}$ as a moderate injury. This standard was deemed appropriately risk averse due to the endangered status of mahseer. Given the lack of significant association between injury and angling variables such as gear type, this standard was likely responsible for the high rate of minor (23 of 39 fish assessed for injury) and moderate (five of 39 fish assessed) injury recorded during the rapid assessment. The rate of foul-hooking (9\%) may also be a result of the use of treble hooked lures in targeting blue-finned mahseer (commonly considered to be an aggressive striking fish). These lures are commonly employed in the study area, but to date less frequently used elsewhere in south India (D. Plummer, Cauvery River angling guide personal communication). Despite this relatively high rate of minor injury (60\%), $91 \%$ of these injuries occurred at the hook site in the mouth. Throughout the study, only one fish was considered likely to die, but no cases of mortality were observed during the study period. Additional mortality can occur after release (i.e. delayed mortality) but fish were generally vigorous at time of release with little reflex impairment (see below) suggesting mortality was unlikely.

Analysis of blood chemistry in angled blue-finned mahseer revealed that longer angling times correlated with increases in blood lactate and glucose, and decreases in blood $\mathrm{pH}$, while longer air exposure times and smaller fish size were found to correlate with higher blood glucose values. The relationship between angling time and key stress markers has been documented in a number of species, including great barracuda (Sphyraena barracuda Edwards; O'Toole et al. 2010) and bonefish (A. vulpes L.; Suski et al. 2007). As with angling time, the relationship between longer air exposure times and increases in blood glucose has also been noted in other popular sport fish, such as largemouth bass (M. salmoides Lacépède; White et al. 2008) and northern pike (Esox Lucius L.; Arlinghaus et al. 2009). The negative relationship between air exposure and fish length in this study, however, is contrary to typical findings that describe larger bodied fish as more likely to exhibit higher stress responses (see Meka \& McCormick 2005). Meka and McCormick (2005) postulated that fish maintaining a higher weight/length ratio may exhibit increased stress response as a result of experiencing more anaerobic exercise (than fish maintaining a lower weight/length ratio) during a stressor of equal duration and intensity. No trophy-sized fish (blue-finned mahseer can attain masses that exceed $50 \mathrm{~kg}$ in this region; Pinder et al. In Press) were landed during the rapid assessment, however, and as mahseer weight was not measured it was not possible to determine whether this hypothesis applies to blue-finned mahseer.

The potential impacts of species-specific stress responses are also important to consider. For example, the amount of variability in blood lactate, glucose and $\mathrm{pH}$ measurements explained by the predictors was low, suggesting that these correlations may be weak in this species. Weak correlations may also be a result of species-specific physiological traits robust to such stressors. Nonetheless, we did observe that quickly angled mahseer (i.e. angled and sampled in $<1 \mathrm{~min}, n=9$ ) had levels of lactate that averaged $3.9 \pm 0.2 \mathrm{mmol} \mathrm{L}^{-1}$ which is presumably indicative of near-baseline values for this species (Romero 2004). The minimum values found in this study for lactate were $1.4 \pm 0.2 \mathrm{mmol} \mathrm{L}^{-1}$ with a maximum of $11.6 \pm 0.2 \mathrm{mmol} \mathrm{L}^{-1}$. Given the potamodromous ecology of mahseer, further study to explore the role of lactate metabolism in mahseer recovery from angling is warranted.

Exploratory analysis of RAMP scores demonstrated that rates of mahseer reflex impairment were relatively low, with the 40 of 49 fish exhibiting no impairment $(N=33)$ or impairment of a single indicator behaviour $(n=7)$. Burst swimming and equilibrium were the most likely to be impaired, followed by loss of torso flexion and irregular operculum beats. While other studies employing RAMP have also found that the burst swimming reflex is most likely to be impaired (for e.g. see Raby et al. 2012; Brownscombe et al. 2013), these studies also found that loss of torso flexion was the second most frequently impaired reflex. During the present rapid assessment, it was noted that body flex in mahseer is less evident than in other species and therefore its presence or absence was less easily visible. Anglers using RAMP to assess the status of landed fish prior to release, or future studies incorporating measurements of RAMP to study mahseer, should consider prioritising indicators other than body flex.

Longer angling and air exposure times were the variables most likely to contribute to non-zero (impaired) RAMP scores. The rate of minor impairment (14\%) in this study further suggests that negative reflex response to these angling stressors is not uncommon in mahseer. Both the contributions of angling variables and this evidence of reflex impairment suggest that further research into the occurrence of sub-lethal effects in mahseer may be advisable. 


\section{Conclusions from rapid assessment and recommended best practices}

The rapid assessment findings suggest mahseer are robust to $\mathrm{C} \& \mathrm{R}$, but also provide data to support the development of best angling practices designed to reduce unnecessarily long angling times and air exposures. While angling times for larger bodied fish are likely to be longer than for smaller fish, anglers should opt for gear choices appropriate to their target species as inappropriate gear choices can result in extended angling times (Meka \& McCormick 2005) and avoid unnecessary delay in landing hooked fish. Handling time may be reduced by using fewer hooks (i.e. single hooks rather than treble hooks) and/or barbless hooks, which may reduce the time needed for hook removal (Cooke et al. 2001). Anglers should also attempt to reduce the amount of time landed fish are subjected to air exposure, particularly in higher water temperatures (Gingerich et al. 2007). In this study, mahseer demonstrated increased blood glucose after air exposures greater than $30 \mathrm{~s}$ in mean water temperatures of $27 \pm 2{ }^{\circ} \mathrm{C}$, which could be considered a conservative maximum for cumulative exposure time in similar conditions.

Future research recommendations include quantifying the physiological stress responses of larger bodied fish (i.e. trophy mahseer) and identifying sub-lethal impacts resulting from angling, particularly those relevant to mahseer natural history (which is understudied in most Tor spp.; Nautiyal 2014). Fish considered to be of trophy size were not targeted or captured in this study. Such mahseer are known to be subject to fight times often exceeding $1 \mathrm{~h}$ (D. Plummer, Cauvery River angling guide, personal communication) and may therefore be more susceptible to delayed recovery and stressinduced mortality. The physiological challenges posed by migration behaviours may increase the likelihood sub-lethal impacts of recreational angling on mahseer at certain times of year (i.e. migratory periods) or in differing environmental conditions (i.e. different water temperatures). It should be noted that mahseer are not typically targeted by C\&R anglers during monsoon season (approximately May-October); however, migration phases may extend beyond monsoon season according to habitat type/life stage (e.g. T. putitora Hamilton is believed to migrate at different times according to age class; Nautiyal 2014). Moreover, information on population size and demographics/life-history characteristics (e.g. age at maturation, natural mortality rates) is needed to understand the level of C\&R-induced mortality than can be considered sustainable - information that is typically absent for endangered species targeted by 6 recreational C\&R anglers (Cooke et al. 2014).

\section{Acknowledgments}

Cooke is supported by the Canada Research Chairs Program and the Natural Sciences and Engineering Research Council of Canada. Danylchuk is supported by the National Institute of Food \& Agriculture, U.S. Department of Agriculture, and the Massachusetts Agricultural Experiment Station and Department of Environmental Conservation. Raghavan is supported by the Mohammed Bin Zayed Species Conservation Fund. Pinder is supported by the Mahseer Trust. We appreciate the logistic support provided by CWS, WASI and our many volunteer anglers, and permission for the study (through CWS) from Ramakrishna, Joint Director of Fisheries, Government of Karnataka. Special thanks go to Neethi Mahesh, Ambily Nair, Shyam Aiyappa, Aiyappa C.P., Dayan Mandappa, Sandeep Chakrabarti, Shine Sathvik, Naren Sreenivasan, Steve Lockett, and Derek D'Souza.

\section{References}

Arlinghaus R., Cooke S.J., Lyman J., Policanksy D., Schwab A., Suski C. et al. (2007) Understanding the complexity of catchand-release in recreational fishing: an integrative synthesis of global knowledge from historical, ethical, social and biological perspectives. Reviews in Fisheries Science 15, 75-167.

Arlinghaus R., Klefoth T., Cooke S.J., Gingerich A. \& Suski C. (2009) Physiological and behavioural consequences of catchand-release angling on northern pike (Esox lucius L.). Fisheries Research 97, 223-233.

Bartholomew A. \& Bohnsack J.A. (2005) A review of catch-andrelease angling mortality with implications for no-take reserves. Reviews in Biology and Fisheries 15, 129-154.

Barton B. (2002) Stress in Fishes: a diversity of responses with particular reference to changes in circulating corticosteroids. Integrative \& Comparative Biology 42, 517-525.

Bower S.D., Nguyen V.M., Danylchuk A.J., Beard T.D. Jr \& Cooke S.J. (2014) 'Inter-sectoral conflict and recreational fisheries of the developing world: Opportunities and challenges for co-operation'. In: P. McConney, R. Medeiros \& M. Pena (eds) Enhancing Stewardship in Small-Scale Fisheries: Practices and Perspectives. Too Big To Ignore (TBTI) and Centre for Resource Management and Environmental Studies, The University of the West Indies, Cave Hill Campus, Barbados. CERMES Technical Report No. 73, 88-97.

Brownscombe J.W., Thiem J.D., Hatry C., Cull F., Haak C.R., Danylchuk A.J. et al. (2013) Recovery bags reduce postrelease impairments in locomotory activity and behavior of bonefish (Albula spp.) following exposure to angling-related stressors. Journal of Marine Biology \& Ecology 440, 207-215.

Cooke S.J. \& Philipp D.P. (2004) Behaviour and mortality of caught-and-released boneftsh (Albula spp.) in Bahamian waters 
with implications for a sustainable recreational fishery. 7 Biological Conservation 118, 599-607.

Cooke S.J. \& Sneddon L.U. (2007) Animal welfare perspectives on catch-and-release recreational angling. Applied Animal Behaviour Science 104, 176-198.

Cooke S.J. \& Suski C.D. (2005) Do we need species-specific guidelines for catch-and-release recreational angling to effectively conserve diverse fishery resources? Biodiversity \& Conservation 14, 1195-1209.

Cooke S.J., Philipp D.P., Dunmall K.M. \& Schreer J.F. (2001) The influence of terminal tackle on injury, handling time and cardiac disturbance of rock bass. North American Journal of Fisheries Management 21, 333-342.

Cooke S.J., Raby G.D., Donaldson M.R., Hinch S.G., O'Connor C.M., Arlinghaus R. et al. (2013) The physiological consequences of catch-and-release angling: perspectives on experimental design, interpretation, extrapolation and relevance to stakeholders. Fisheries Management \& Ecology 20, 268287.

Cooke S.J., Hogan Z.S., Butcher P.A., Stokesbury M.J.W., Raghavan R., Gallagher A.J. et al. (In Press) Angling for endangered fish: conservation problem or conservation action? Fish \& Fisheries ?????,???????-??????

Davis M.W. (2010) Fish stress and mortality can be predicted using reflex impairment. Fish \& Fisheries 11, 1-11.

Everard M. \& Kataria G. (2011) Recreational angling markets to advance the conservation of a reach of the Western Ramganga River, India. Aquatic Conservation: Marine and Freshwater Ecosystems 21, 101-108.

Gingerich A.J., Cooke S.J., Hanson K.C., Donaldson M.R., Hasler C.T., Suski C.D. et al. (2007) Evaluation of the interactive effects of air exposure duration and water temperature on the condition and survival of angled and released fish. Fisheries Research 86, 169-178.

Gutowsky L.F.G., Harrison P.M., Landsman S.J., Power M. \& Cooke S.J. (2011) Injury and mortality associated with recreational troll capture of bull trout (Salvelinus confluentus) in a reservoir in the Kootenay-Rocky Mountain region of British Columbia. Fisheries Research 109, 379-383.

IUCN (2014) IUCN Red List of Threatened Species. Version 2014.3. www.iucnredlist.org. Downloaded on 17 November 2014.

Meka J.L. \& McCormick S.D. (2005) Physiological response of wild rainbow trout to angling: impact of angling duration, fish size, body condition and temperature. Fisheries Research $\mathbf{7 2}$, 311-322.

Muoneke M.I. \& Childress W.M. (1994) Hooking mortality: a review for recreational fisheries. Reviews in Fisheries Science 2, 123-156.

Nautiyal P. (2014) Review of the art and science of Indian mahseer (game fish) from nineteenth to twentieth century: road to extinction or conservation? Proceedings of the National Academy of Science, India, Section B, Biological Sciences 84, 215-236.
Nguyen V.M., Martins E.G., Robichaud D., Raby G.D., Donaldson M.R., Lotto A.G. et al. (2014) Disentangling the roles of air exposure, gill net injury, and facilitated recovery on the post capture and release mortality and behaviour of adult migratory sockeye salmon (Oncorhynchus nerka) in freshwater. Physiological \& Biochemical Zoology 87, 127-1353.

O'Toole A.C., Danylchuk A.J., Suski C.D. \& Cooke S.J. (2010) Consequences of catch-and-release angling on the physiological status, injury, and immediate mortality of great barracuda (Sphyraena barracuda) in The Bahamas. ICES Journal of Marine Science 67, 1667-1675.

Pankhurst N.W. \& Van Der Kraak G. (1997) 'Effects of stress on reproduction and growth of fish' In: G.K. Iwama, J. Sumpter, A.D. Pickering \& C.B. Schreck (eds) Fish Stress and Health in Aquaculture. Society for Experimental Biology Seminar Series 62, Cambridge University Press, Cambridge, UK, pp. 73-95.

Pinder A.C. \& Raghavan R. (2013) Conserving the endangered mahseers (Tor spp.) of India: the positive role of recreational fisheries. Current Science India 104, 1472-1475.

Pinder A.C., Raghavan R. \& Britton R. (In Press) Efficacy of angler catch data as a population and conservation monitoring tool for the flagship Mahseer fishes (Tor spp.) of Southern India. Aquatic Conservation: Marine and Freshwater Ecosystems 00, 000-000. doi:10.1002/aqc.2543

Raby G.D., Donaldson M.R., Hinch S.G., Patterson D.A., Lotto A.G., Robichaud D. et al. (2012) Validation of reflex indicators for measuring vitality and predicting the delayed mortality of wild coho salmon bycatch released from gears. Journal of Applied Ecology 49, 90-98.

Raghavan R., Ali A., Dahanukar N. \& Rosser A. (2011) Is the Deccan mahseer, Tor khudree (Sykes, 1839) (Pisces: Cyprinidae) fishery in the Western Ghats hotspot sustainable? A participatory approach to stock assessment. Fisheries Research 110, 29-38.

Romero L.M. (2004) Physiological stress in ecology: lessons from biomedical research. Trends in Ecology \& Evolution 19, 249-255.

Skomal G.B. (2007) Evaluating the physiological and physical consequences of capture on post-release survivorship in large pelagic fishes. Fisheries Management \& Ecology 14, 81-89.

Stoot L.J., Cairns N.A., Cull F., Taylor J.J., Jeffrey J.D., Morin F. et al. (2014) Use of portable blood physiology point-of-care devices for basic and applied research on vertebrates - a review. Conservation Physiology 2, cou011.

Suski C.D., Cooke S.J., Danylchuk A.J., O'connor C.M., Gravel M.A., Redpath T. et al. (2007) Physiological disturbance and recovery dynamics of bonefish (Albula vulpes), a tropical marine fish, in response to variable exercise and exposure to air. Comparative Biochemistry \& Physiology, Part A 148, 664-673.

White A.J., Schreer J.F. \& Cooke S.J. (2008) Behavioural and physiological responses of the congeneric largemouth (Micropterus salmoides) and smallmouth (M. dolomieu) to 
various exercise and air exposure durations. Fisheries Research 89, 9-16.

WWF- India (2013) In: P. Nautiyal, S. Babu \& S. Behera (eds) Mahseer Conservation in India: Status, Challenges and the Way Forward. New Delhi, INR: WWF-India, 38 p.
Zuur A., Ieno E.N., Walker N., Saveliev A.A. \& Smith G.M. (2009) 'Mixed effects models and extensions with R'. In: M. Gail, K. Krickeberg, J.M. Samet, A. Tsiatis \& W. Wong (eds) Statistics for Biology and Health. Springer, NY, USA, $574 \mathrm{p}$. 


\section{Author Query Form}

Journal: $\quad$ FME

Article: $\quad 12135$

Dear Author,

During the copy-editing of your paper, the following queries arose. Please respond to these by marking up your proofs with the necessary changes/additions. Please write your answers on the query sheet if there is insufficient space on the page proofs. Please write clearly and follow the conventions shown on the attached corrections sheet. If returning the proof by fax do not write too close to the paper's edge. Please remember that illegible mark-ups may delay publication.

Many thanks for your assistance.

\begin{tabular}{|c|c|c|}
\hline Query reference & Query & Remarks \\
\hline 1 & $\begin{array}{l}\text { AUTHOR: Please confirm that given names (red) and surnames/family } \\
\text { names (green) have been identified correctly. }\end{array}$ & \\
\hline 2 & $\begin{array}{l}\text { AUTHOR: FAO } 2012 \text { has not been included in the Reference List, please } \\
\text { supply full publication details. }\end{array}$ & \\
\hline 3 & $\begin{array}{l}\text { AUTHOR: Barton et al. } 2002 \text { has been changed to Barton } 2002 \text { so that } \\
\text { this citation matches the Reference List. Please confirm that this is correct. }\end{array}$ & \\
\hline 4 & $\begin{array}{l}\text { AUTHOR: Please provide city name for Becton, Dickson and Company } \\
\text { (BD). }\end{array}$ & \\
\hline 5 & $\begin{array}{l}\text { AUTHOR: Figure } 4 \text { was not cited in the text. An attempt has been made } \\
\text { to insert the figure into a relevant point in the text - please check that this } \\
\text { is OK. If not, please provide clear guidance on where it should be cited in } \\
\text { the text. }\end{array}$ & \\
\hline 6 & $\begin{array}{l}\text { AUTHOR: Cooke et al. } 2014 \text { has not been included in the Reference List, } \\
\text { please supply full publication details. }\end{array}$ & \\
\hline 7 & $\begin{array}{l}\text { AUTHOR: Cooke and Philipp (2004) has not been cited in the text. Please } \\
\text { indicate where it should be cited; or delete from the Reference List. }\end{array}$ & \\
\hline 8 & $\begin{array}{l}\text { AUTHOR: Please provide the year of publication, volume number and } \\
\text { page range for reference Pinder. }\end{array}$ & \\
\hline 9 & $\begin{array}{l}\text { AUTHOR: Skomal (2007) has not been cited in the text. Please indicate } \\
\text { where it should be cited; or delete from the Reference List. }\end{array}$ & \\
\hline 10 & $\begin{array}{l}\text { AUTHOR: Figure } 1 \text { has been saved at a low resolution of } 264 \text { dpi. Please } \\
\text { resupply at } 600 \mathrm{dpi} \text {. Check required artwork specifications at http:// } \\
\text { authorservices.wiley.com/bauthor/illustration.asp }\end{array}$ & \\
\hline
\end{tabular}

